\title{
Single Platinum Atoms Electrocatalysts: Oxygen Reduction and Hydrogen Oxidation Reactions
}

\author{
Miomir B. Vukmirovic, * Krishani M. Teeluck, Ping Liu, Radoslav R. Adzic\#
}

Chemistry Division, Brookhaven National Laboratory, Upton, NY

* Corresponding author's e-mail address: miomir@bnl.gov

\# Corresponding author's e-mail address: adzic@bnl.gov

RECEIVED: May 27, 2017 « REVISED: June 23, 2017 « ACCEPTED: June 29, 2017

THIS PAPER IS DEDICATED TO PROF. MIRJANA METIKOŠ-HUKOVIĆ ON THE OCCASION OF HER BIRTHDAY

\begin{abstract}
Atomically dispersed catalyst consisting of Pt atoms arranged in a $c(2 \times 2)$ array on $\mathrm{RuO}_{2}(110)$ substrate was prepared. A large interatomic distance of Pt atoms in a $\mathrm{c}(2 \times 2)$ phase precludes the reactants to interact with more than one Pt atoms. A strong bond of Pt atoms with $\mathrm{RuO}_{2}$ prevents agglomeration of $\mathrm{Pt}$ atoms to form 2D-islands or 3D-clusters. Activities of single $\mathrm{Pt}$ atom catalyst for the oxygen reduction and hydrogen oxidation reactions were determined and compared with those of bulk Pt. It has lower catalytic activity for the oxygen reduction reaction and similar activity for hydrogen oxidation reaction compared to Pt(111). This was explained by a large calculated up-shift of the $d-$ band center of Pt atoms and larger Pt-Pt interatomic distance than that of Pt(111). This information is of considerable interest for further development of electrocatalysis.
\end{abstract}

Keywords: single atom, monolayers, platinum, oxygen reduction reaction, hydrogen oxidation reaction.

\section{INTRODUCTION}

$\mathbf{T}$ HE approaching era of depleted fossil resources drives automobile industry to find solution that will not only replace internal combustion engines (ICE) but also to be environmentally friendly. Proton Exchange Membrane Fuel Cells (PEMFCs) are strong candidate for automotive applications having many advantages compared to other means of energy conversion. In contrast to ICE, fuel cells in general are not bound by the Carnot cycle laws. They directly convert chemical energy of fuel to electrical energy with efficiency which is considerably higher than that of ICEs. In addition to several other useful features, a major environmental benefit is expected if renewable fuels, like hydrogen, are used. The hydrogen can be produced by water electrolysis using energy from renewable sources like sun or wind. This completes energy cycle which can reduce our dependence on fossil-fuels and eliminate the detrimental effects of fossil-fuel consumption on environment.

$\mathrm{Pt}$ is the major component of both anode and cathode fuel cell catalysts. Its price is high, it has low natural abundance, and although it is the best catalyst, it suffers from performance limitations. The sluggishness of electrocatalytic oxygen reduction reaction (ORR) is main loss of performance of PEMFCs. Additional performance loss comes if reformate hydrogen is used as a fuel. Catalysts poisoning, that reduces the rate of the hydrogen oxidation reaction (HOR), is caused by CO adsorption, ${ }^{[1]}$ which is a common contaminant in $\mathrm{H}_{2}$ produced by steam reforming of hydrocarbons or small alcohols.

The reduction of the amount of Pt with simultaneous improvements in performance is usually achieved by alloying Pt with less noble metals. ${ }^{[2-4]} \mathrm{A}$ common approach for better utilization of $\mathrm{Pt}$ is by increasing its dispersion, i.e. reduction of Pt particle size. For the $\mathrm{ORR}^{[5-8]}$ and $\mathrm{HOR}^{[9]}$ activity dependence on particle size is well documented in numerous publications. This is usually explained by changing in electronic (smaller nanoparticles become more non-metal-like) and geometric (ensemble effect) properties of nanoparticles with the reduction of their size. A novel approach to address the large Pt content, insufficient activity and durability drawbacks of existing catalysts represents the so-called Pt monolayer catalysts (single Pt atoms shell on a metal, alloy or oxide core), and other core-shell catalysts. ${ }^{[10-14]}$ 
Although a $100 \%$ Pt utilization can be achieved with specific procedure of electrodepositing a Pt monolayer, ${ }^{[15]}$ a maximum utilization of the expensive and scarce Pt can be also achieved by atomically dispersing Pt on catalysts' supports. Such catalysts reflect the reaction kinetics on single Pt atoms. These make a system of uniform active sites, each having the same geometry and same electronic properties since every metal atom is in the same chemical environment. As such, they represent an ideal system for investigating electrochemical reactions mechanisms with the possibility to eliminate some reaction steps that simplifies determining the mechanism. One possibility for synthesizing single atom catalysts we mentioned in 2007.[16] Interest for these catalysts is growing. ${ }^{[17]}$ Their synthesis is a complex procedure and making them safe from agglomeration during chemical reaction is another level of difficulties. ${ }^{[17,18]}$

In this paper, we describe one method to obtain atomically dispersed catalyst consisting of $\mathrm{Pt}$ atoms on $\mathrm{RuO}_{2}(110)$ substrate and its characterization. Furthermore, we determined the activities of single Pt atom catalyst for the ORR and HOR and compared them with those of bulk Pt. This information is of considerable interest for further development of electrocatalysis.

\section{EXPERIMENTAL}

Preparation of $\mathrm{RuO}_{2}(110)$ single-crystal surface, obtained by the gas-phase oxidation of $\mathrm{Ru}(0001)$, was described elsewhere. ${ }^{[19]}$ Following mechanical polishing with $1 \mu \mathrm{m}$ diamond paste, disk-shaped Ru(0001) single crystal $(8 \mathrm{~mm}$ in diameter and $2 \mathrm{~mm}$ thick) was cleaned and placed inside a quartz tube. The surface oxidation was carried out in mixture of $\mathrm{Ar}$ and $\sim 100 \mathrm{ppm} \mathrm{O}_{2}$ gases by inductive heating for $2 \mathrm{~min}$ at temperatures between 600 and $800 \mathrm{~K}$.

Atomically dispersed Pt deposition on $\mathrm{RuO}_{2}(110)$ was described elsewhere. ${ }^{[20]}$ The method involves the following steps: (i) adsorption of $\mathrm{Pb}$ cations on $\mathrm{RuO}_{2}(110)$ surface by immersing the sample in $0.1 \mathrm{mM} \mathrm{Pb}\left(\mathrm{ClO}_{4}\right)_{2}+0.1 \mathrm{M}$ $\mathrm{NaOH}$, (ii) electrochemical reduction of adsorbed $\mathrm{Pb}$ cations in $0.1 \mathrm{M} \mathrm{NaOH}$ solution, and (iii) galvanic displacement of $\mathrm{Pb}$ adatoms with $\mathrm{Pt}$ by immersion in a $1 \mathrm{mM} \mathrm{K}_{2} \mathrm{PtCl}_{4}+50$ $\mathrm{mM} \mathrm{H}_{2} \mathrm{SO}_{4}$. All solutions were deaerated and all these steps were carried out in an enclosure containing glassware with appropriate solution and regular electrochemical cell. The enclosure was filled with Ar to prevent the oxidation of $\mathrm{Pb}^{0}$ adatoms in contact with $\mathrm{O}_{2}$.

An in situ electrochemical scanning tunneling microscopy (ECSTM) study was performed using a Molecular Imaging Pico STM with a 300 S scanner, 300S Pico Bipotentiostat, and a PicoScan 2500 controller (Keysight Technologies model 5500, controller model N9605A). The tunneling tips were made of a polycrystalline Pt-20\%Ir wire, coated with Apiezon wax. The cell was made of Teflon, and Pt wires served as the reference and counter electrodes. The ECSTM pictures were obtained in $50 \mathrm{mM} \mathrm{H}_{2} \mathrm{SO}_{4}$ under open circuit conditions $(\sim 0.95 \mathrm{~V})$.

The voltammetry experiments were carried out in a standard three-electrode electrochemical cell with a $\mathrm{Ag} / \mathrm{AgCl} / \mathrm{KCl}(3 \mathrm{M})$ reference electrode and a Pt foil counter electrode. All the potentials in the text are reported with respect to a reversible hydrogen electrode (RHE). All the solutions were made with high-purity grade chemicals and Millipore Q UV plus water.

\section{RESULTS AND DISCUSSION}

\section{Pt Atoms on $\mathrm{RuO}_{2}(110)$ Substrate $\left(\mathrm{Pt}_{\mathrm{at}} / \mathrm{RuO}_{\mathbf{2}}(\mathbf{1 1 0})\right)$}

The $\mathrm{RuO}_{2}(110)$ surface was chosen as a model system because of its unique suitability for atomic scale surface chemistry, its electrical conductivity and stability under the oxidizing conditions typical in oxygen cathodes. It was obtained by oxidation of $\mathrm{Ru}(0001)$ by $\mathrm{O}_{2}(100 \mathrm{ppm})$ in $\mathrm{Ar}$ at elevated temperatures. ECSTM images reveal that oxide grows as long parallel stripes (Figure 1a). The step height of these stripes is about $3 \AA$, corresponding to one monolayer of Ru oxide. The structure of the oxide stripes was unveiled by atomically resolved ECSTM pictures (Figure 1b). It consists of array of bright spots with a rectangular $6.3 \AA$ × $3.1 \AA$ unit cell. Within the limits of accuracy of the ECSTM technique, this unit cell corresponds to the rutile structure of $\mathrm{RuO}_{2}$ with the $(110)$ orientation $\left(6.38 \AA \times 3.11 \AA\right.$ ).$^{[21]}$ The coverage of $\mathrm{Ru}$ oxide was examined by comparing voltammetry curves of $\mathrm{Ru}(0001)$ and $\mathrm{RuO}_{2}(110)$ in $0.1 \mathrm{M}$ $\mathrm{NaOH}$. The absence of characteristic hydrogen adsorption $\mathrm{Ru}$ peaks shown in Figure 2 is an indication that the $\mathrm{Ru}$ surface is fully covered with $\mathrm{RuO}_{2}(110)$.

Atomically dispersed $\mathrm{Pt}$ layer deposited on $\mathrm{RuO}_{2}(110)$ was obtained by procedure described in Experimental section. The atomically resolved ECSTM image (Figure 3 a) of Pt deposit reveals that it consists of bright spots (Pt atoms) arranged in a $c(2 \times 2)$ array $(6.0 \AA \times 13.3 \AA)$. The deposit is equivalent to the 0.25 monolayer Pt coverage ( $\mathrm{Pt}$ coverage was calculated in relation to Ru atoms). This structure, seen in Figure $3 b$, was predicted by density functional theory (DFT) ${ }^{[22]}$ calculations showing that Pt atoms lie $\sim 1 \AA$ above the plane of bridging $\mathrm{O}$ of $\mathrm{RuO}_{2}(110) .{ }^{[16]}$ This is understandable since Pt atoms cannot lie in the plane of Ru atoms because the Pt-Ru distance would be too short, making such configurations energetically unfavorable.

\section{Hydrogen Oxidation Reaction}

Figure 4a shows voltammetry curves for $\mathrm{Pt}_{\mathrm{at}} / \mathrm{RuO}_{2}(110)$ and $\mathrm{RuO}_{2}(110)$ in deaerated $0.1 \mathrm{M} \mathrm{HClO}_{4}$. Comparison of these 

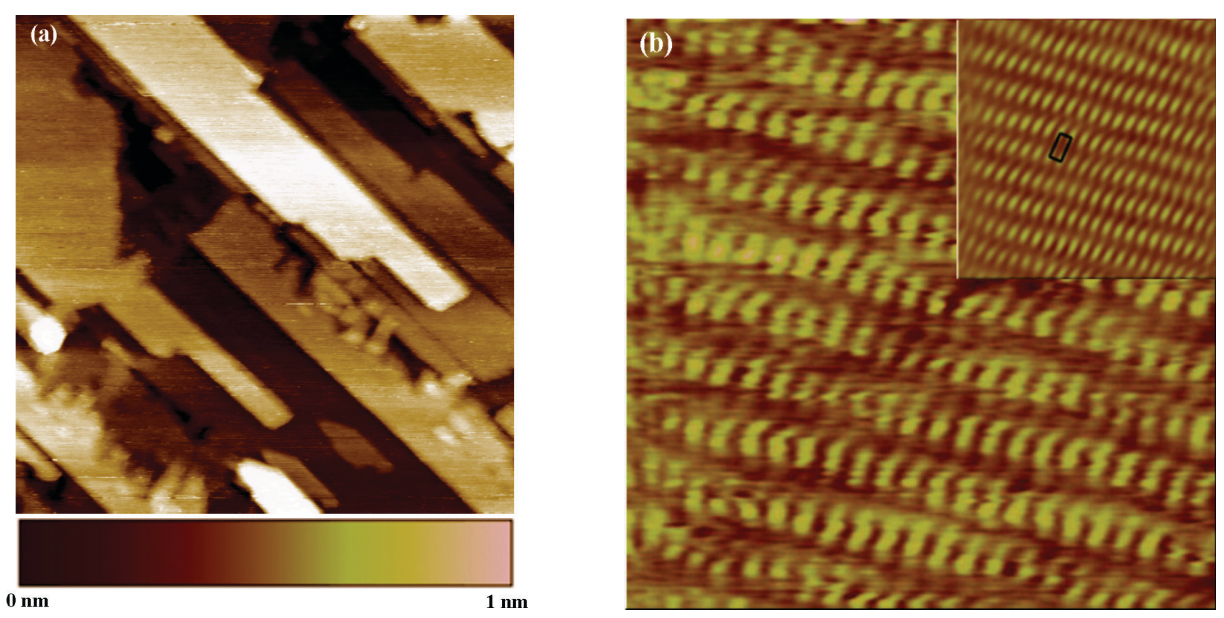

Figure 1. (a) ECSTM image of the $\mathrm{RuO}_{2}(110)$ oxide obtained by chemical oxidation of $\mathrm{Ru}(0001)$; size $200 \mathrm{~nm} \times 200 \mathrm{~nm}$, $\mathrm{Z}$ range $1 \mathrm{~nm}$. (b) Atomically resolved ECSTM image of $\mathrm{RuO}_{2}$ stripes and its Fourier transform shown in the inset; size $5.8 \mathrm{~nm} \times 5.8 \mathrm{~nm}$. Images were obtained in $50 \mathrm{mM} \mathrm{H}_{2} \mathrm{SO}_{4}$ at open circuit condition (0.95 V). Reprinted (adapted) with permission from Ref. [16]. Copyright (2007) American Chemical Society.

two curves reveals some differences between them in potential range $0.05-0.6 \mathrm{~V}$. Since there is no $\mathrm{H}$ underpotential deposition (UPD) on $\mathrm{RuO}_{2}(110)$, the feature in 0.05-0.2 V potential range could be ascribed to the $\mathrm{H}$ UPD on $\mathrm{Pt}_{\mathrm{at}}$ / $\mathrm{RuO}_{2}$ (110). Theoretical value for $\mathrm{H}$ UPD charge for Pt(111) is $240 \mu \mathrm{C} \mathrm{cm}{ }^{-2}$, while experimentally observed charge is $160 \mu \mathrm{C} \mathrm{cm}^{-2}$ due to overlap of H UPD and hydrogen evolution. ${ }^{[23]}$ Since there are 6 times more Pt atoms on a Pt(111) surface than on the $\mathrm{Pt}_{\mathrm{at}} / \mathrm{RuO}_{2}(110)$, to make comparison on the same basis of H UPD charge of these two surfaces, the measured $\mathrm{H}$ UPD charge for $\mathrm{Pt}_{\text {at }} / \mathrm{RuO}_{2}(110)$ is multiplied by 6 and the value of $50 \mu \mathrm{C} \mathrm{cm}^{-2}$ is obtained. Although

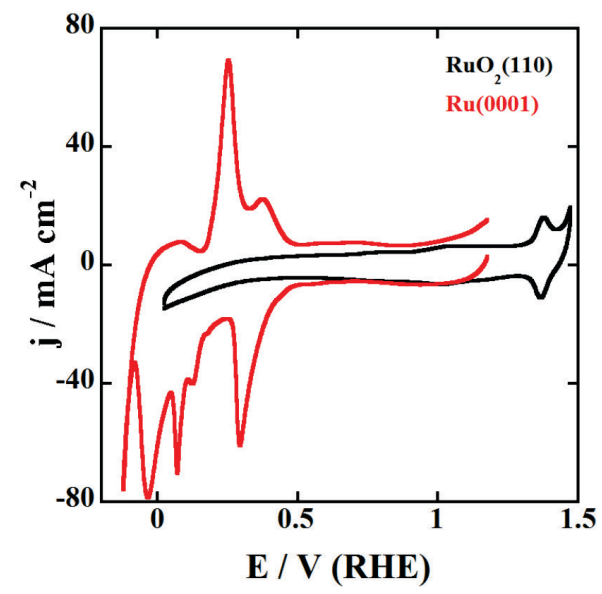

Figure 2. Voltammetry curves for the $\mathrm{Ru}(0001)$ and $\mathrm{RuO}_{2}(110)$ in deoxygenated $0.1 \mathrm{M} \mathrm{NaOH}$, sweep rate $20 \mathrm{mV} \mathrm{s}^{-1}$. Reprinted (adapted) with permission from Ref. [20]. Copyright (2016) John Wiley \& Sons Inc.

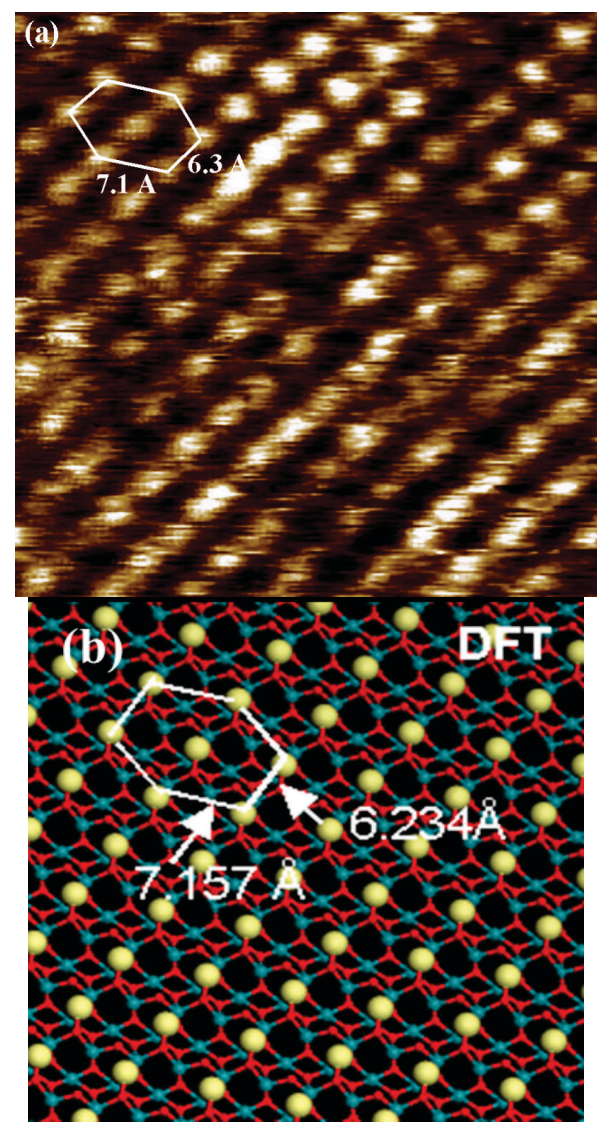

Figure 3. (a) ECSTM image $(3.9 \mathrm{~nm} \times 3.9 \mathrm{~nm})$ of the $\mathrm{Pt}_{\mathrm{at}}$ deposit on $\mathrm{RuO}_{2}(110)$ obtained in $50 \mathrm{mM} \mathrm{H}_{2} \mathrm{SO}_{4}$ at open circuit condition (0.95 V). Reprinted (adapted) with permission from Ref. [16]. Copyright (2007) American Chemical Society. (b) Optimized geometry for 0.25 monolayer Pt coverage on $\mathrm{RuO}_{2}(110)$ in perspective view obtained by DFT calculations. 

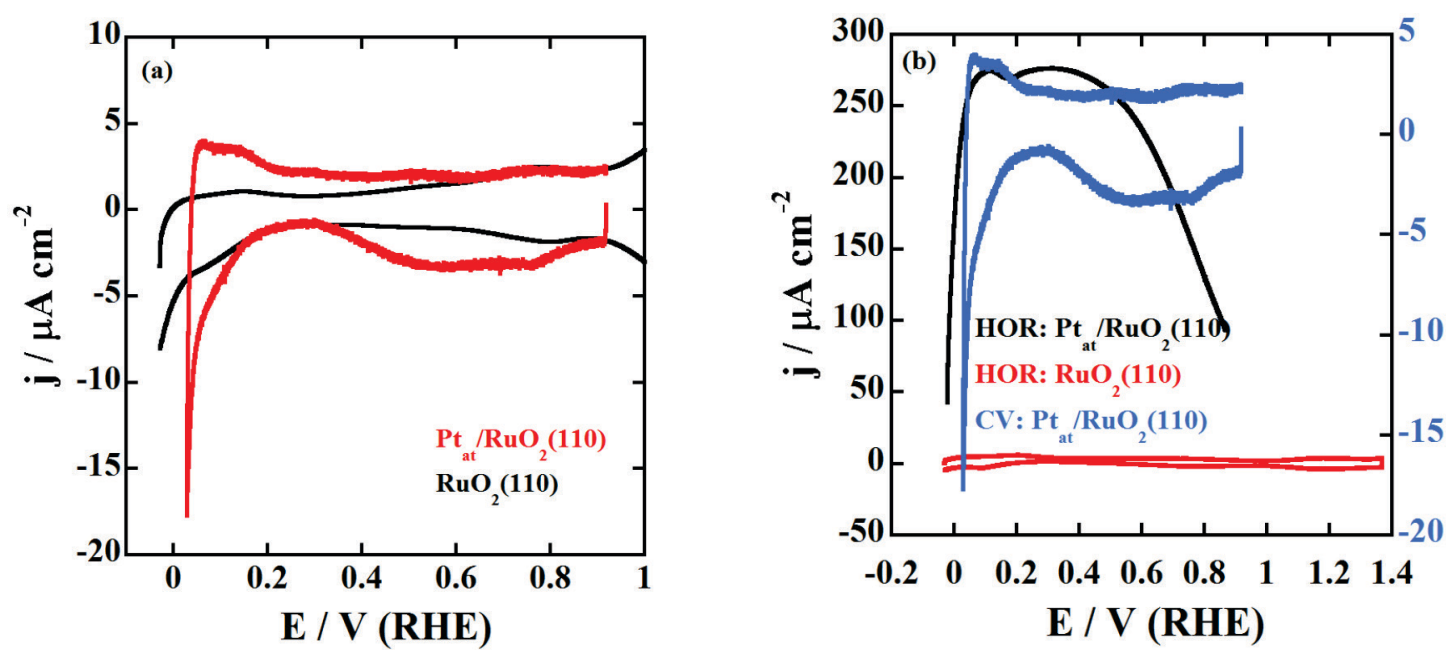

Figure 4. (a) Voltammetry curves for $\mathrm{Pt}_{\text {at }} / \mathrm{RuO}_{2}(110)$ and $\mathrm{RuO}_{2}(110)$ in deaerated $0.1 \mathrm{M} \mathrm{HClO}_{4}$. (b) Voltammetry curves for the $\mathrm{HOR}$ on $\mathrm{Ptat}_{\mathrm{at}} / \mathrm{RuO}_{2}(110)$ and $\mathrm{RuO}_{2}(110)$ stationary electrodes in $\mathrm{H}_{2}$ saturated $0.1 \mathrm{M} \mathrm{HClO}_{4}$. The voltammetry curve for $\mathrm{Pt}_{\text {at }} /$ $\mathrm{RuO}_{2}(110)$ in deareated $0.1 \mathrm{M} \mathrm{HClO}_{4}$ is added for comparisons. Sweep rate $20 \mathrm{mV} \mathrm{s}^{-1}$.

its value is lower than expected one, for which we do not have an explanation, it still supports our assertion about identity of the feature in $0.05-0.2 \mathrm{~V}$ potential range. In contrast to H UPD on $\mathrm{Pt}(111),{ }^{[24]}$ where $\mathrm{H}(\mathrm{ad})$ occupies multifold adsorption site (three-fold symmetry hollow site), this observation suggest that $\mathrm{H}(\mathrm{ad})$ can adsorb on a single $\mathrm{Pt}$ atom. It is interesting that for $\mathrm{Pd}, \mathrm{H}$ adsorption requires at least dimers. ${ }^{[25]}$

The feature in $0.2-0.6 \mathrm{~V}$ potential range could be assigned to the oxidation of $\mathrm{Pt}(\mathrm{Pt}-\mathrm{OH})$. The distance between Pt atoms in Pt adlayer (Figure $3 \mathrm{~b}$ ) is considerably larger than the one in $\mathrm{Pt}(111)$. However, atoms are close enough to electronically interact with each other. That causes an up-shift in energy of the d-band center of a $\mathrm{Pt}_{\text {at }}$ / $\mathrm{RuO}_{2}(110)^{[22]}$ making $\mathrm{Pt}$ easier to be oxidized. This is additionally supported by the observation that HOR current starts to decrease at the beginning of Pt oxidation process.

Voltammetry curves for the HOR on $\mathrm{Pt}_{\mathrm{at}} / \mathrm{RuO}_{2}(110)$ and $\mathrm{RuO}_{2}(110)$ stationary electrodes are displayed in Figure 4b. The voltammetry curve for $\mathrm{Pt}_{\mathrm{at}} / \mathrm{RuO}_{2}(110)$ in deareated $0.1 \mathrm{M} \mathrm{HClO}_{4}$ is added for comparisons. Current close to zero value for $\mathrm{RuO}_{2}(110)$ indicates that HOR does not proceed on $\mathrm{RuO}_{2}(110)$ and that only Pt overlayer is active for HOR. According to the Tafel-Heyrovsky-Volmer mechanism, that describes the HOR on $\mathrm{Pt}$, there are three elementary reaction steps for $\mathrm{HOR}\left(\mathrm{H}_{2} \rightarrow 2 \mathrm{H}^{+}+2 \mathrm{e}^{-}\right)$on Pt catalysts. ${ }^{[26]}$

$$
\begin{aligned}
& \mathrm{H}_{2}+2 \mathrm{Pt} \rightarrow 2(\mathrm{H}-\mathrm{Pt}) \quad(\text { Tafel }) \\
& \mathrm{H}_{2}+\mathrm{Pt} \rightarrow \mathrm{H}-\mathrm{Pt}+\mathrm{H}^{+}+\mathrm{e}^{-} \quad \text { (Heyrovsky) } \\
& \mathrm{H}-\mathrm{Pt} \rightarrow \mathrm{Pt}+\mathrm{H}^{+}+\mathrm{e}^{-} \quad \text { (Volmer) }
\end{aligned}
$$

Tafel step, which represents the dissociative adsorption of a hydrogen molecule, is not possible due to large PtPt interatomic distance in the Pt overlayer. Consequently, only Heyrovsky -Volmer pathway is possible requiring one $\mathrm{Pt}$ site. In addition, the limiting current density is reached above $80 \mathrm{mV}$ indicating fast kinetics. This is unexpected result, since it is known that rapid increase in current at low overpotentials $(<50 \mathrm{mV})$ is due to Tafel-Volmer pathway while Heyrovsky-Volmer pathway is operative at larger overpotentials (> $50 \mathrm{mV}$ ) enabling a more gradual increase in HOR current on bulk Pt. ${ }^{[26]}$ This result can be explained by the up-shift of the d-band center of a $\mathrm{Pt}_{\text {at }} / \mathrm{RuO}_{2}(110)^{[22]}$ which leads to an increase in hydrogen binding energy. ${ }^{[27]}$ This increase in hydrogen binding energy will boost the slower kinetics of the Heyrovsky-Volmer mechanism thus resulting in the fast increase in current at low overpotentials. The validity of this assertion is tested by comparing HOR currents per atom for $\mathrm{Pt}_{\mathrm{at}} / \mathrm{RuO}_{2}(110)$ and $\mathrm{Pt}(111)$ samples. The current per atom at potential of $15 \mathrm{mV}$ for $\mathrm{Pt}_{\text {at }} / \mathrm{RuO}_{2}(110)$ is $0.8610^{-18} \mathrm{~A} /$ atom. This value is similar to the one for $\mathrm{Pt}(111)\left(0.5510^{-18} \mathrm{~A}\right.$ ( atom). That indicates that single Pt atom is sufficient for HOR to occur and that can maintain similar hydrogen oxidation rate like $\mathrm{Pt}$ atoms in $\mathrm{Pt}(111)$. It is interesting to note that $\mathrm{H}(\mathrm{ad})$ as a HOR intermediate and $\mathrm{H}$ from H UPD compete for the same active sites. Since kinetics of Heyrovsky-Volmer mechanism is increased rather than decreased, our results indicate that there is no site-blocking effect of H UPD as discussed in literature. ${ }^{[28]}$

\section{Oxygen Reduction Reaction}

Figure 5a compares voltammetry curves for the ORR on $\mathrm{Pt}_{\mathrm{at}} /$ $\mathrm{RuO}_{2}(110), \mathrm{RuO}_{2}(110)$ and $\mathrm{Pt}(111)$ stationary electrodes in 

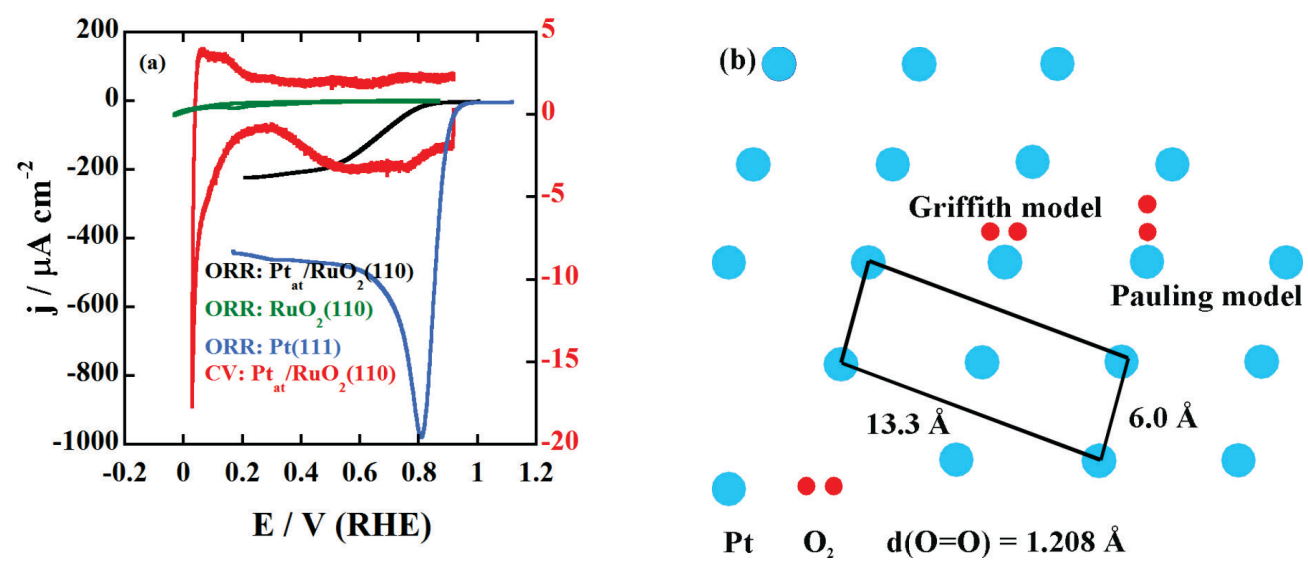

Figure 5. (a) Voltammetry curves for ORR on $\mathrm{Ptat}_{\mathrm{at}} / \mathrm{RuO}_{2}(110), \mathrm{RuO}_{2}(110)$, and $\mathrm{Pt}(111)$ stationary electrodes in oxygenated $0.1 \mathrm{M} \mathrm{HClO}_{4}$. The voltammetry curve for $\mathrm{Pt}_{\mathrm{at}} / \mathrm{RuO}_{2}(110)$ in deareated $0.1 \mathrm{M} \mathrm{HClO}_{4}$ is added for comparisons. Sweep rate $20 \mathrm{mV} \mathrm{s}^{-1}$, and (b) model depicting the bonding of $\mathrm{O}_{2}$ with Pt atoms of the $\mathrm{Pt}_{\mathrm{at}} / \mathrm{RuO}_{2}(110)$ sample. Reprinted (adapted) with permission from Ref. [20]. Copyright (2016) John Wiley \& Sons Inc.

oxygenated $0.1 \mathrm{M} \mathrm{HClO}_{4}$ and voltammetry curve for $\mathrm{Pt}_{\text {at }}$ / $\mathrm{RuO}_{2}(110)$ in deareated $0.1 \mathrm{M} \mathrm{HClO}_{4}$. It can be noticed that ORR does not occur on $\mathrm{RuO}_{2}(110)$ indicating that ORR activity of $\mathrm{Pt}_{\mathrm{at}} / \mathrm{RuO}_{2}(110)$ is due to the presence of Pt. However, $\mathrm{Pt}_{\mathrm{at}} /$ $\mathrm{RuO}_{2}(110)$ displayed lower ORR activity compared to Pt(111) as seen by the negative shift of onset potential and smaller kinetic current. The lower ORR activity of $\mathrm{Pt}_{\mathrm{at}} / \mathrm{RuO}_{2}(110)$ compared to $\mathrm{Pt}(111)$ is due to observation that $\mathrm{Pt}$ in $\mathrm{Pt}_{\text {at }} /$ $\mathrm{RuO}_{2}(110)$ oxidizes at lower potentials compared to Pt(111). ${ }^{[29,30]}$ From Figure 5a, it can be seen that ORR current of $\mathrm{Pt}_{\mathrm{at}} / \mathrm{RuO}_{2}(110)$ increases concurrently with $\mathrm{Pt}-\mathrm{OH}$ reduction.

Besides this, such activity could be due to the fact that active site consists of single atom thus restricting possible geometries of $\mathrm{O}_{2}$ adsorption. The distance between these single Pt atoms is larger than the one on Pt(111) surface. Therefore bonding of $\mathrm{O}_{2}$ with two nearby $\mathrm{Pt}$ atoms (bridge model - Yeager) is impossible and a simple splitting of the $\mathrm{O}-\mathrm{O}$ bond does not take place. So only possibility is that $\mathrm{O}_{2}$ bonds to a single Pt atom either by two bonds (Griffith model) or by end-on adsorption through a single bond (Pauling model), Figure 5b. ${ }^{[31]}$ Although $\mathrm{O}_{2}$ molecule can adsorb in a bridge configuration between a Pt atom and a Ru atom, such adsorption, if it happens, does not appear to improve the activity. A possible reason for this is that the presence of an oxygen-containing species at a $\mathrm{RuO}_{2}$ surface in a broad potential range will interfere with the ORR.

\section{CONCLUSIONS}

We describe the method to form a Pt adlayer, $c(2 \times 2)$ phase on $\mathrm{RuO}_{2}(110)$ substrate. A large interatomic distance of Pt atoms in a $\mathrm{c}(2 \times 2)$ phase precludes the reactants to interact with more than one Pt atoms. A strong bond of Pt atoms with $\mathrm{RuO}_{2}(110)$ and a rigid adlayer structure prevent agglomeration of $\mathrm{Pt}$ atoms. With such a surface, we determined the activities of single Pt atom catalyst for the oxygen reduction and hydrogen oxidation reactions. Single Pt atoms have lower catalytic activity for the oxygen reduction reaction and similar activity for hydrogen oxidation reaction as the atoms in $\mathrm{Pt}(111)$. This was explained by a large calculated up-shift of the d-band center of Pt atoms and larger Pt-Pt interatomic distance than that of $\mathrm{Pt}(111)$. This effect increases the kinetics of $\mathrm{HOR}$, but decreases the ORR by increased $\mathrm{PtOH}$ coverage above $0.4 \mathrm{~V}$. This information is of considerable interest for further development of electrocatalysis.

Acknowledgment. This manuscript has been authored by employees of Brookhaven Science Associates, LLC under Contract No. DE-SC0012704 with the U.S. Department of Energy. The publisher by accepting the manuscript for publication acknowledges that the United States Government retains a non-exclusive, paid-up, irrevocable, world-wide license to publish or reproduce the published form of this manuscript, or allow others to do so, for United States Government purposes.

\section{REFERENCES}

[1] J. X. Wang, S. R. Brankovic, Y. Zhu, J. C. Hanson, R. R. Adzic, J. Electrochem. Soc. 2003, 150, A1108.

[2] I. E. L Stephens, A. S. Bondarenko, U. Grønbjerg, J. Rossmeisl, I. Chorkendorff, Energy Environ. Sci. 2012, 5, 6744.

[3] S. Mukerjee, J. McBreen, J. Electrochem. Soc. 1996, 143, 2285. 
[4] T. Sato, K. Okaya, K. Kunimatsu, H. Yano, M. Watanabe, H. Uchida, ACS Catal. 2012, 2, 450.

[5] M. Nesselberger, S. Ashton, J. C. Meier, I. Katsounaros, K. J. J. Mayrhofer, M. Arenz, J. Am. Chem. Soc. 2011, 133, 17428.

[6] K. Shinozaki, Y. Morimoto, B. S. Pivovar, S. S. Kocha, Electrochim. Acta 2016, 213, 783.

[7] F. J. Perez-Alonso, D. N. McCarthy, A. Nierhoff, P. Hernandez-Fernandez, C. Strebel, I. E. L. Stephens, J. H. Nielsen, I. Chorkendorff, Angew. Chem. Int. Ed. 2012, 51, 4641.

[8] S. E. F. Kleijn, S. C. S. Lai, M. T. M. Koper, P. R. Unwin, Angew. Chem. Int. Ed. 2014, 53, 3558.

[9] Y. Sun, Y. Dai, Y. Liu, S. Chen, Phys. Chem. Chem. Phys. 2012, 14, 2278.

[10] K. Sasaki, H. Naohara, Y. Cai, Y. M. Choi, P. Liu, M. B. Vukmirovic, J. X. Wang, R. R. Adzic, Angew. Chem. Int. Ed. 2010, 49, 8602.

[11] A. Kongkanand, N. P. Subramanian, Y. Yu, Z. Liu, H. Igarashi, D. A. Muller, ACS Catal. 2016, 6, 1578.

[12] A. Kongkanand, M. F. Mathias, J. Phys. Chem. Lett. 2016, 7, 1127.

[13] K. Elbert, J. Hu, Z. Ma, Y. Zhang, G. Chen, W. An, P. Liu, H. S. Isaacs, R. R. Adzic, J. X. Wang, ACS Catal. 2015, 5, 6764.

[14] Y.-C. Hsieh, Y. Zhang, D. Su, V. Volkov, R. Si, L. Wu, Y. Zhu, W. An, P. Liu, P. He, S. Ye, R. R. Adzic, J. X. Wang, Nat. Commun. 2013, 4, 2466.

[15] S. Bliznakov, M. Vukmirovic, R. Adzic in AtomicallyPrecise Methods for Synthesis of Solid Catalysts, No. 22 (Eds.: S. Hermans, T. V. de Bocarme), RSC Catalysis Series, The Royal Society of Chemistry, 2015, 144-166.

[16] M. B. Vukmirovic, P. Liu, J. T. Muckerman, R. R. Adzic, J. Phys. Chem. C 2007, 111, 15306.
[17] J. Jones, H. Xiong, A. T. DeLaRiva, E. J. Peterson, H. Pham, S. R. Challa, G. Qi, S. Oh, M. H. Wiebenga, X. I. P. Hernández, Y. Wang, A. K. Datye, Science 2016, 353, 150.

[18] A. Neitzel, A. Figueroba, Y. Lykhach, T. Skála, M. Vorokhta, N. Tsud, S. Mehl, K. Ševčíková, K. C. Prince, K. M. Neyman, V. Matolín, J. Libuda, J. Phys. Chem. C 2016, 120, 9852.

[19] M. B. Vukmirovic, R. L. Sabatini, R. R. Adzic, Surf. Sci. 2004, 572, 269.

[20] M. B. Vukmirovic, K. A. Kuttiyiel, H. Meng, R. R. Adzic, ChemElectroChem 2016, 3, 1635.

[21] Lj. Atanasoska, W. E. O'Grady, R. T. Atanasoski, F. H. Pollak, Surf. Sci. 1988, 202, 142.

[22] P. Liu, J. T. Muckerman, R. R. Adzic, J. Chem. Phys. 2006, 124, 141101.

[23] N.M. Marković, N.S. Marinković, R.R. Adžić, J. Electroanal. Chem. 1988, 241, 309.

[24] G. Jerkiewicz, Prog. Surf. Sci. 1998, 57, 137.

[25] F. Maroun, F. Ozanam, O. M. Magnussen, R. J. Behm, Science 2001, 293, 1811.

[26] J. X. Wang, T. E. Springer, R. R. Adzic, J. Electrochem. Soc. 2006, 153, A1732.

[27] S. Kandoi, P. A. Ferrin, M. Mavrikakis, Top. Catal. 2010, 53, 384.

[28] N. M. Markovic, B. N. Grgur, P. N. Ross, J. Phys. Chem. B 1997, 101, 5405.

[29] N. M. Markovic, R. R. Adzic, B. D. Cahan, E. B. Yeager, J. Electroanal. Chem. 1994, 377, 249.

[30] N. Markovic, H. Gasteiger, P. N. Ross, J. Electrocherm. Soc. 1997, 144, 1591.

[31] R. R. Adzic in Frontiers in Electrochemistry: Electrocatalysis, (Eds.: J. Lipkowski, P. N. Ross), Wiley-VCH Publishers, New York, 1998, pp. 197242. 